\title{
Wild birds as pets in Campina Grande, Paraíba State, Brazil: An Ethnozoological Approach
}

\author{
MORGANA R. LICARIÃO ${ }^{1}$, DANDARA M.M. BEZERRA ${ }^{2}$ and RÔMULO R.N. ALVES ${ }^{3}$ \\ ${ }^{1}$ Programa de Pós-Graduação em Ciência e Tecnologia Ambiental, Universidade Estadual da Paraíba, \\ Av. das Baraúnas, 351, Campus Universitário, Bodocongó, 58109-753 Campina Grande, PB, Brasil \\ ${ }^{2}$ Programa de Pós-Graduação em Ciências Biológicas, Universidade Federal da Paraíba, \\ Departamento de Sistemática e Ecologia, Campus 1, Cidade Universitária, 58059-900 João Pessoa, PB, Brasil \\ ${ }^{3}$ Departamento de Biologia, Universidade Estadual da Paraíba, \\ Av. das Baraúnas, 351, Campus Universitário, Bodocongó, 58109-753 Campina Grande, PB, Brasil
}

Manuscript received on January 31, 2011; accepted for October 24, 2011

\begin{abstract}
Birds are one of the animals most widely used by humans and are highly valued as pets. The present work reports the use of wild birds as pets in the city of Campina Grande, Paraíba State (PB), Brazil. The owners' choice and perceptions of the species ecology was assessed as well. The methodology employed included unstructured and semi-structured interviews, guided tours and direct observations. A total of 26 bird species distributed among ten families and four orders were identified. The most frequently encountered order was Passeriformes (76.9\%), with a predominance of the family Emberizidae (34.6\%). The specimens kept as pets were principally obtained in public markets or between the breeders themselves. The popularity of birds as pets, compounded by the inefficiency of official controls over the commerce of wild animals has stimulated the illegal capture and breeding of wild birds in Campina Grande.
\end{abstract}

Key words: Avifauna, bird breeders, commerce in wild birds, conservation, ethnozoology, ethno-ornithology.

\section{INTRODUCTION}

Animals have been used by indigenous societies and by the descendents of the European colonists in Brazil since the colonial period (Almeida 2005, Alves et al. 2007, Alves and Souto 2011). Wild animals have traditionally been used for a wide variety purposes, including as foods and in cultural activities, and their body parts or sub-products serve as adornments, tools, and for medicinal and magic-religious purposes (Rocha et al. 2006, 2008, Trinca and Ferrari 2006, Alves et al. 2007, 2008a,

Correspondence to: Rômulo Nobrega Alves E-mail: romulo_nobrega@yahoo.com.br b, 2009a, b, 2010a, b, c, 2011, 2012a, b, c, d, Alves and Pereira-Filho 2007, Leo Neto et al. 2009, 2011, 2012, Confessor et al. 2009, Ferreira et al. 2009, Tôrres et al. 2009, Oliveira et al. 2010, Dias et al. 2011, Rosa et al. 2011, Alves 2012).

Bird-keeping activities are common throughout Brazil in both rural and urban settings (Sick 1997, Alves et al. in press), and these birds rarely come from legalized breeders, however, they are mostly captured in the wild (Gama and Sassi 2008, Alves et al. 2010a). Most bird species are traded for pets, although a few species are traded for food and (to a far lesser extent) medicinal and folk magic 
purposes (Alves and Rosa 2007, 2010, Alves 2009, Alves and Alves 2011, Souto et al. 2011, Alves et al. in press). Trafficking wild animals, especially birds, is one of the most characteristic segments of illegal commerce Brazil. This type of trafficking is undertaken principally to supply specimens for collectors, zoos, scientists, and pet shops and public markets throughout the world (Alves et al. in press).

Birds are one of the animal groups most widely used by human populations. Many birds are kept simply for their beauty, but many of them are valued for their singing and are kept as pets or sold. It is a very common practice to keep birds as pets (Rocha et al. 2006, Alves et al. 2009a, 2010a, 2012b, FernandesFerreira et al. 2012) and captive Passeriformes are readily observed (or heard) in bars and restaurants, stores, shoe repair shops and homes in the smallest towns and the largest cities in northeastern Brazil. Rarely, however, these birds were acquired from registered breeders (Gama and Sassi 2008).

An important step in guaranteeing the sustainable use of the local/regional fauna is understanding the relationships that have been established between human and the animals in question, including the species most frequently taken and their different uses. Ethnoscientific studies are fundamental to this process (Alves and Albuquerque 2012) and ethno-ornithology is specifically directed towards examining popular knowledge about birds (Sick 1997, Tidemann and Gosler 2010) and it is essential to prepare conservation and management strategies as birds have very significant ecological, economic, and cultural importance to human populations.

Alves et al. (2008b, 2010b) pointed out that the ways in which natural resources are used by human populations are extremely relevant to defining conservation strategies. This will be particularly true in the Caatinga (dryland) region of northeastern Brazil, as the people are greatly dependent on the direct use of local natural resources for survival (Albuquerque et al. 2012, Alves et al. 2012c). This social reality makes it senseless to attempt to draw up conservation strate- gies for the Caatinga biome without considering the role of human populations and the impacts generated by their use of regional natural resources.

In spite of the fact that the native fauna is widely used in northeastern Brazil, very few studies have been published on this theme (Alves et al. 2009a, 2012a, Barbosa et al. 2011, Bezerra et al. 2012). The widespread removal of animals from their natural habitats for commercial gain or for amateur captive breeding creates enormous challenges for the governmental agencies responsible for wildlife protection (Vidolin et al. 2004). As such, studies examining fauna use by human populations are essential for developing environmental education programs and wildlife management plans (Alves et al. in press).

The present work reports the use of wild birds as pets in the city of Campina Grande, Paraíba State (PB), Brazil, and characterizes how these animals are acquired, the owners motives and ecological perceptions. We describe here the basic relationships between humans and wild birds to provide fundamental information for future actions directed towards the conservation and sustainable management of the ornitofauna of Paraíba State.

\section{MATERIALS and METHODS}

DESCRIPTION OF THE STUDY AREA

The municipality of Campina Grande is located in Paraíba State in northeastern Brazil (7 $7^{\circ} 13^{\prime} 11^{\prime \prime}$ $\mathrm{S}$ and $35^{\circ} 52^{\prime} 31^{\prime \prime} \mathrm{W}$ ) (Rodrigues et al. 1996). The municipality has a population of 371,060 (IBGE 2008) (Figure 1) and occupies an area of $621 \mathrm{~km}^{2}$ in the eastern sector of the Borborema Highlands (550 meters above sea level) (IBGE 2008). The region has an undulating topography and a semi-arid equatorial climate with average temperatures between $22^{\circ} \mathrm{C}$ and $25^{\circ} \mathrm{C}$. The vegetation near Campina Grande includes "agreste" (dry arboreal formations), "brejo" (highaltitude humid forests), and "cariri" or "caatinga" (dryland) areas (Rocha et al. 2006). 


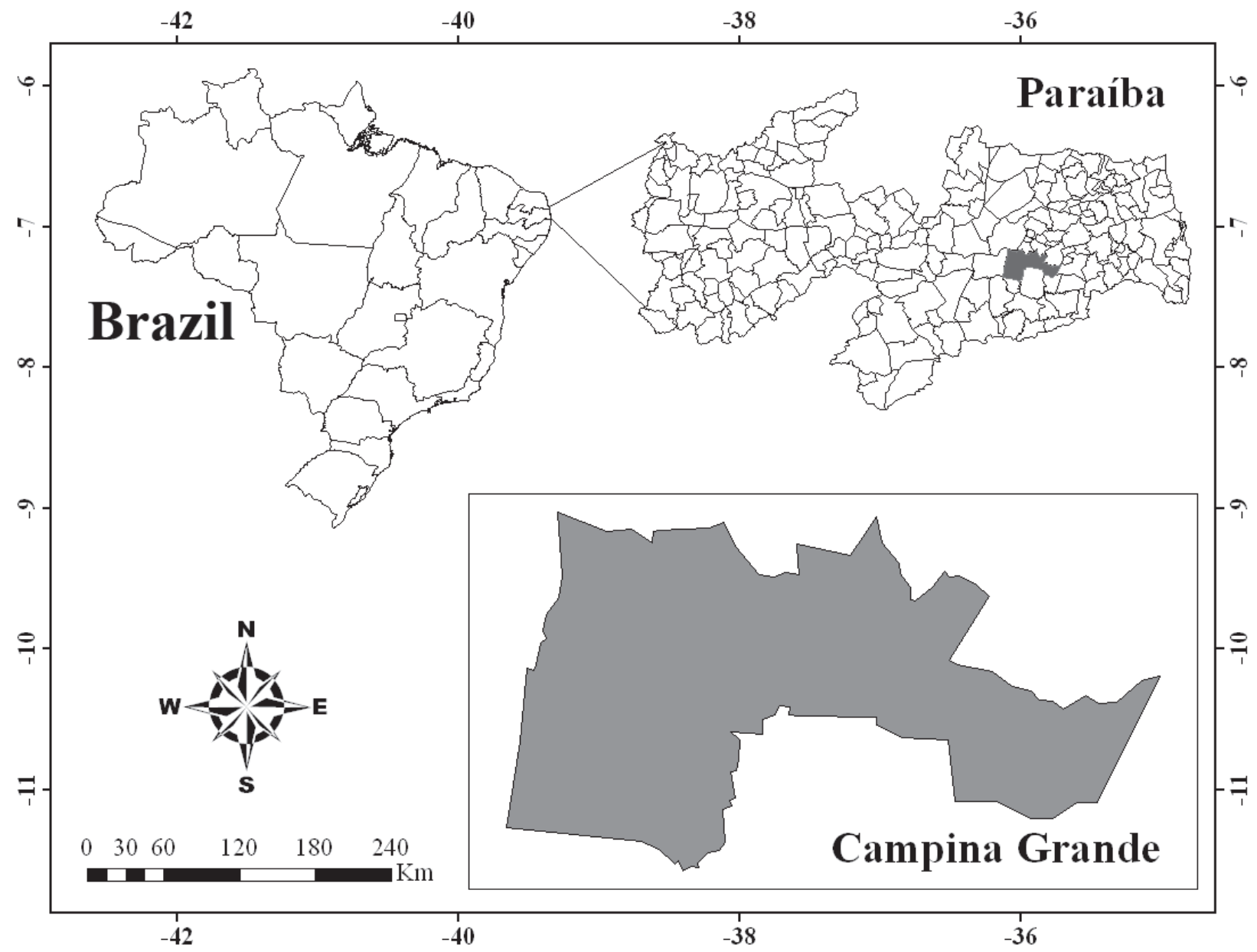

Figure 1 - Map of the study area; municipality of Campina Grande, Paraíba State, Brazil.

Methodological Procedures

Research was carried out between April and November, 2008. Visits were made to the homes of 50 bird breeders in eight different neighborhoods (José Pinheiro, Monte Castelo, Belo Monte, Nova Brasília, Vila Cabral, Centro, Alto Branco and Bodocongó) in the city of Campina Grande. The 50 breeders interviewed included 12 women and 38 men, with ages varying from 14 to 70 years. The research project was approved by the Research Ethics Committee of the Universidade Estadual da Paraíba (protocol number 0364.0.133.000-08).

Initial contacts were designed to establish a rapport of mutual confidence between the researchers and the interviewees, and consisted of unstructured and non-organized interviews (Costa-Neto and Marques 2000). The unstructured interviews allowed us to develop the "snow-ball" technique (Bailey 1982), in which the interviewees (in this case, experienced breeders) would indicate yet others, thus creating a sequence of indications that allowed us to identify those people with the greatest experience in keeping birds.

These unstructured interviews were followed by semi-structured interviews designed to obtain detailed information about the personal knowledge of each breeder: the names of the birds they kept, why they kept them, how they obtained the birds, how they took care of them, and their natural 
ecology. The interviews employed a methodology that incorporated every-day expressions used by the interviewees themselves (Posey 1986). The interviews were recorded in writing, and the data was subsequently organized into standardized archives.

A good amount of information relating to the species being kept and how they were housed, treated and fed could be gleaned by direct observations in the homes of the interviewees. The birds were photographed and their local names recorded according to the information provided by the owners. The scientific identifications of the birds were made by direct observations and through photographs taken during the course of the interviews and confirmed by consulting the specialized literature (Perlo 2009, Ridgely and Tudor 2009, CBRO 2011).
The scientific nomenclature of the species follows the recommendations of the Comitê Brasileiro de Registros Ornitológicos (CBRO 2011).

The qualitative data was analyzed using an emic/etic approach (Costa-Neto and Marques 2000) in which traditional knowledge was compared with corresponding and/or correlated information in the scientific literature.

\section{RESULTS and DISCUSSION}

THE BIRDS ENCOUNTERED

A total of 180 specimens of wild birds were encountered in the residences we visited, comprising 26 species distributed among ten families and four orders (Table I).

TABLE I

Species of wild birds encountered in the homes of breeders in Campina Grande, Paraíba State, Brazil.

\begin{tabular}{|c|c|c|c|}
\hline & TAXA & LOCAL NAME & NUMBER OF BIRDS \\
\hline \multicolumn{4}{|l|}{ Tinamiformes Huxley, 1872} \\
\hline Tinamidae Gray, 1840 & Nothura boraquira (Spix, 1825) & Codorna & 06 \\
\hline \multicolumn{4}{|l|}{ Columbiformes Latham, 1790} \\
\hline \multirow[t]{2}{*}{ Columbidae Leach, 1820} & Columba livia (Gmelin, 1789) & Pombo & 10 \\
\hline & Columbina talpacoti (Temminck, 1811) & Rolinha-cambuto & 01 \\
\hline \multicolumn{4}{|l|}{ Psittaciformes Wagler, 1758} \\
\hline \multirow[t]{3}{*}{ Psittacidae Rafinesque, 1815} & Amazona aestiva (Linnaeus, 1758) & Papagaio & 04 \\
\hline & Aratinga cactorum (Kuhl, 1820) & Gangarra/Maroca & 07 \\
\hline & Diopsittaca nobilis (Linnaeus, 1758) & Maracanã-nobre & 01 \\
\hline \multicolumn{4}{|l|}{ Passeriformes Linné, 1758} \\
\hline Cardinalidae Ridgway, 1901 & Cyanoloxia brissonii (Lichtenstein, 1823) & Azulão & 32 \\
\hline Corvidae Leach, 1820 & Cyanocorax cyanopogon (Wied, 1821) & Can-cão & 01 \\
\hline \multirow[t]{9}{*}{ Emberizidae Vigors, 1825} & Arremon taciturnus (Hermann, 1783) & Salta-caminho & 06 \\
\hline & Sicalis flaveola (Linnaeus, 1766) & Canário-da-terra & 06 \\
\hline & Sporophila caerulescens (Vieillot, 1823) & Papa-capim mineiro & 03 \\
\hline & Sporophila albogularis (Spix, 1825) & Golado/Golinha & 18 \\
\hline & Sporophila bouvreuil (Statius Muller, 1776) & Cabocolino & 05 \\
\hline & Sporophila lineola (Linnaeus, 1758) & Bigode & 12 \\
\hline & Sporophila nigricollis (Vieillot, 1823) & Papa-capim & 13 \\
\hline & Volatinia jacarina (Linnaeus, 1766) & Tiziu/Nego-tiziu & 02 \\
\hline & Zonotrichia capensis (Statius Muller, 1776) & Tico-tico & 05 \\
\hline Fringillidae Leach, 1820 & Euphonia violacea (Linnaeus, 1758) & Gaturamo & 07 \\
\hline
\end{tabular}


TABLE I (CONTINUATION)

\begin{tabular}{lll}
\hline & TAXA & LOCAL NAME \\
\hline & Sporagra yarrellii (Audubon, 1839) & Pintassilgo/Pintassilva \\
Icteridae Vigors, 1825 & Chrysomus ruficapillus (Vieillot, 1819) & Corda-negra \\
& Icterus jamacaii (Gmelin, 1788) & Concriz \\
Icteridae Vigors, 1825 & Turdus rufiventris (Vieillot, 1818) & Sabiá-laranjeira \\
Thraupidae Cabanis, 1847 & Saltator similis (d'Orbigny \& Lafresnaye, 1837)* & Trinca-ferro \\
& Paroaria dominicana (Linnaeus, 1758) & Galo-de-campina \\
& Lanio pileatus (Wied, 1821) & Maria-fita/Cravina \\
& Tangara sayaca (Linnaeus, 1766) & Sanhaçú \\
& & 01 \\
\hline
\end{tabular}

Passeriformes represented $76.9 \%$ of the total number of bird specimens encountered, followed by the orders Psittaciformes (11.5\%), Columbiformes (7.7\%), and Tinamiformes (3.9\%). Similar results have been reported by other researchers in other regions of northeastern Brazil, with Passeriformes appearing consistently as the most commonly captured (Ferreira and Glock 2004, Costa 2005, Pereira and Brito 2005, Souza and SoaresFilho 2005, Rocha et al. 2006, Gama and Sassi 2008, Pagano et al. 2009, Alves et al 2012b) and confiscated birds (RENCTAS 2001). Passeriformes include the majority of the song-birds preferred by both commercial dealers and the general population.

We encountered a predominance of birds from the families Emberizidae (34.6\%), Thraupidae
(15.5\%), Psittacidae (11.6\%) (Figure 2). These results are again in agreement with previous studies showing that many species of the family Emberizidae are kept and sold as pets in different regions in Brazil (Ferreira and Glock 2004, Costa 2005, Souza and Soares-Filho 2005, Alves et al. in press). The songs of the Emberizidae are much appreciated (Frisch 1981), making them the most sought after taxon among wild bird traffickers (Sick 1997). In their study of bird breeders in the region around Feira de Santana in Bahia State, Freitas (1998) determined that $61.2 \%$ of the species captured were Emberizidae, and $7.3 \%$ Psittacidae. Similar results were likewise noted in a survey of the avifauna kept as pets in the municipality of Catolé da Rocha, Paraíba State (Alves et al. 2010a).

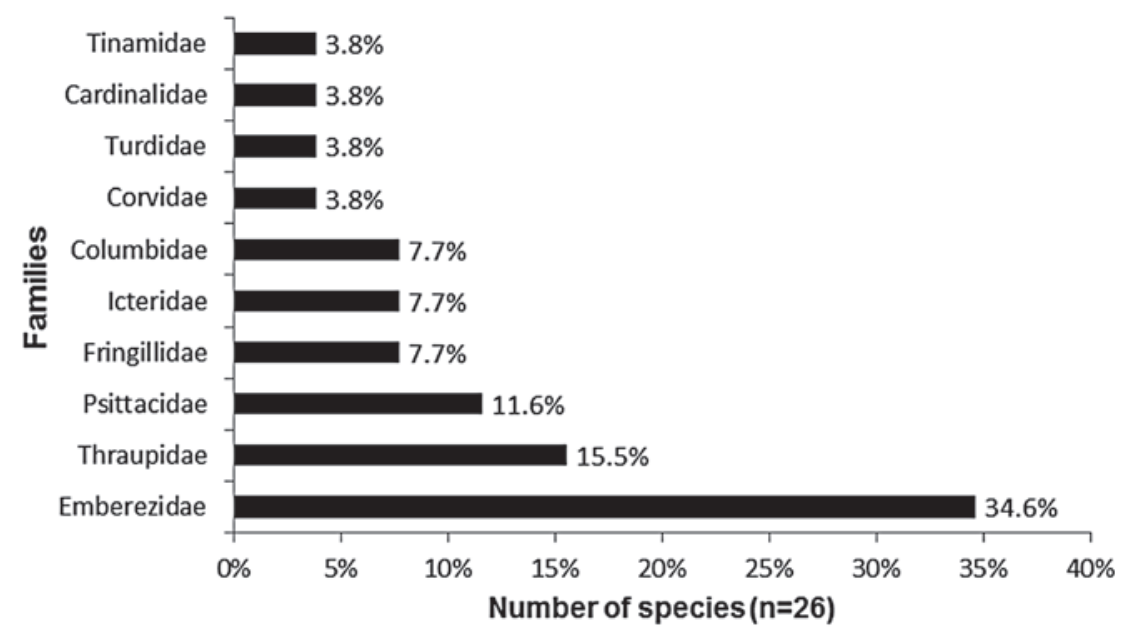

Figure 2 - Bird families encountered in the homes of bird breeders. 
A total of 51 specimens of the genus Sporophila were encountered in the current survey. Gama and Sassi (2008) noted that the species of this genus are greatly appreciated for their singing and are also relatively easy to maintain in captivity - which helped make them the most popular taxa kept as pets in Paraíba State at the time of the study. Pagano et al. (2009) likewise noted a preference for Sporophila in Paraíba State, with the low prices of these species in public markets probably contributing to their popularity.

The species most frequently encountered in Campina Grande were: Cyanoloxia brissonii (32 specimens) and Paroaria dominicana (21 specimens), corresponding to $17.78 \%$ and $11.66 \%$ of the total number of birds encountered respectively.

\section{Methods of ACQUisition}

The manners in which these birds were acquired by breeders did not vary greatly. As shown in Figure $3,84 \%$ of the breeders bought their birds either directly from other breeders or in public markets in Campina Grande, Paraíba State. The buying and selling of birds in public markets is quite common in the city in spite of being illegal (Alves et al. in press). This information corroborated the work of Rocha et al. (2006) who reported the sale of 21 species of wild birds in public markets in the city of Campina Grande. Likewise, Gama and Sassi (2008) reported commerce involving 20 bird species in public markets in the city of João Pessoa (the capital of Paraíba State).

Only $6 \%$ of the breeders captured birds as well as bought them. These animals were taken in rural areas using small snap-cages ("assaprão" or "alçapão") or fall-traps ("arapuca"). It is also fairly common to use nets for capturing wild birds in Paraíba State. Nets allow hunters to capture large numbers of birds - which are then kept in crowded cages called "ajuntadores" to be later separated by species, sex, and/or age. According to Gama and Sassi (2008), these "ajuntadores" cages are often so crowded that the birds have almost no space to move, and many specimens die due to injuries sustained during capture and/or transport. These authors also pointed out that the factor that most determines the death or survival of these specimens is the manner in which they are kept during transport.

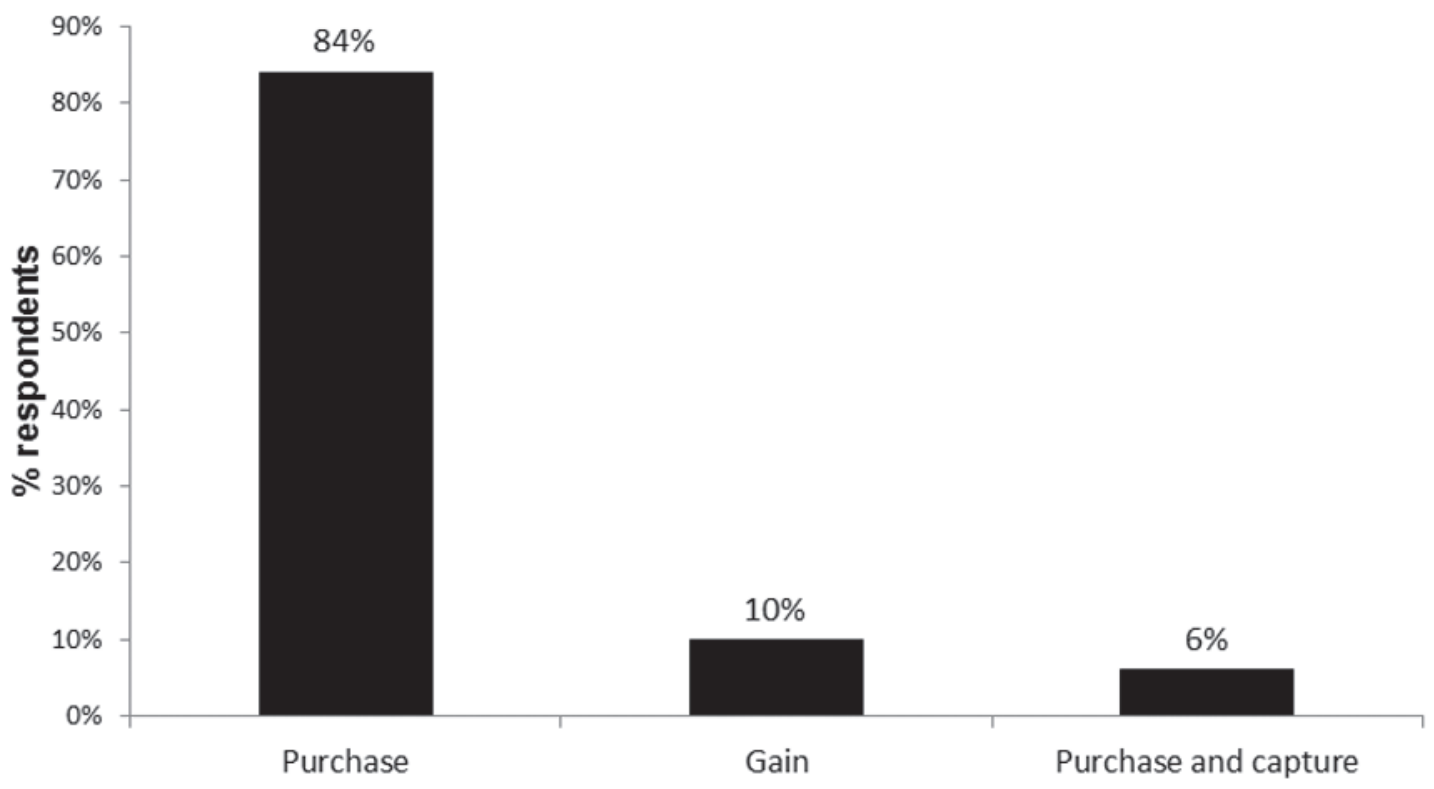

Figure 3 - The manners how pet birds were acquired. 


\section{KEEPING THE BIRDS}

The breeders keep birds in cages or aviaries of various dimensions, and these are generally made of wire or wood. Each cage is reserved for a single bird; the presence of more than one bird in a cage is usually restricted to mating pairs or small families of the same species. Large numbers of birds of the same species, or even of different species, are often housed in aviaries (depending on the sizes of these compounds).

The sizes of the cages are directly related to the sizes of the birds being kept. The breeders also pointed out that cage size may be determined by the sex of the bird, with females generally being kept in smaller cages as they have lower commercial value (being used principally for procreation and to stimulate the singing males).

Some birds, as species of the families Columbidae (pigeons) and Psittacidae (Parrots), for example, are maintained free in backyards, inside the houses, or in open cages called "poleiros". One of the breeders stated that would cut some of the primary remiges of one of the wings (leaving them with different sizes) to prevent the bird from flying.

The cages or aviaries where the birds are kept are cleaned every day (or at least two or three times a week). The breeders cited a number of different foods that they offered to their birds according to the preferences of each species. Seeds and fruits, and foods eaten by humans composed the most frequent items in the diets of these birds. Some species are kept to more restrictive regimes, while others are fed wider assortments of foods. Food can be offered every day, on alternating days, or when the 'cocho' (feeding trough) becomes empty. Birds that eat fruits must receive fresh fruits daily. Allgayer and Cziulik (2007) noted that offering the correct food is of basic importance for successful captive breeding.

In addition to food, the breeders often supply the birds with vitamin supplements to keep them healthy and with good appearances, and singing strongly.
These supplements can be bought in veterinary pharmacies and are usually mixed with the food or the drinking water. The breeders change the drinking water on a daily basis, or at least on alternate days.

Some breeders will hang bird cages on bare walls so that the birds can chip out sand grains (from the walls); some owners will place small friable stones inside the cages, or mix sand with the dry feed. This practice is related to the habit that some birds have of ingesting small stones that aid in grinding/digesting their food (Juras 2006).

According to the interviewees, captive birds are susceptible to a number of diseases, especially parasites. The principal symptoms shown by an ill bird are a lack of singing activity and a general lack of movement within the cage. The recuperation of sick birds often requires a diagnosis and treatment by a veterinarian. These specialists are consulted by most breeders when they cannot identify the cause of the bird's illness themselves or do not know which medicine should be used to treat it. However, the breeders will generally treat the birds without any orientation from a specialist if they recognize the disease and know which treatment is most effective. This type of knowledge is acquired through exchanging information with other bird breeders, relatives, or through personal experiences.

\section{MOTIVES FOR KEEPING BIRDS}

Birds are kept in captivity because they are aesthetically attractive to their owners (with conspicuous colors) and decorate living environments, because of their singing, for the simple satisfaction of having a pet at home as company, or for their commercial value. According to Santos and Costa-Neto (2007), humans commonly incorporate bird species into their lives and may establish strong emotional links with these animals.

When questioned about the reasons for keeping birds in their houses, $26 \%$ of the owners replied 
that they kept them simply because they liked little birds ("bichinhos") and the amusement that they provided. Some species, such as the Blue-fronted Amazon parrot (Amazona aestiva) are usually kept un-caged and will "talk" with their owners. A total of $26 \%$ of the bird owners maintained these animals as a hobby or sport; $20 \%$ of the breeders cite their appreciation for the birds songs; $10 \%$ live alone or feel alone (and the presence of birds in their homes acts as "company", or even therapy); $8 \%$ professed a love of nature (although the birds were captive, some owners felt that the simple presence of an animal in their home brought them closer to nature); $6 \%$ of the breeders replied that they had had birds in their homes since they were infants; and 4\% received their birds as presents.

Fully $34 \%$ of the interviewees had kept birds as pets since they were children (Figure 4) - which indicates the cultural tradition of raising birds as pets and as a practice passed from father to son. A total of $86 \%$ of the people interviewed currently kept birds, while $14 \%$ were ex-breeders. This latter group explained that they had given up raising birds fairly recently due to a lack of time to dedicate themselves fully to this hobby, or for fear of being fined by the federal wildlife agency (IBAMA).

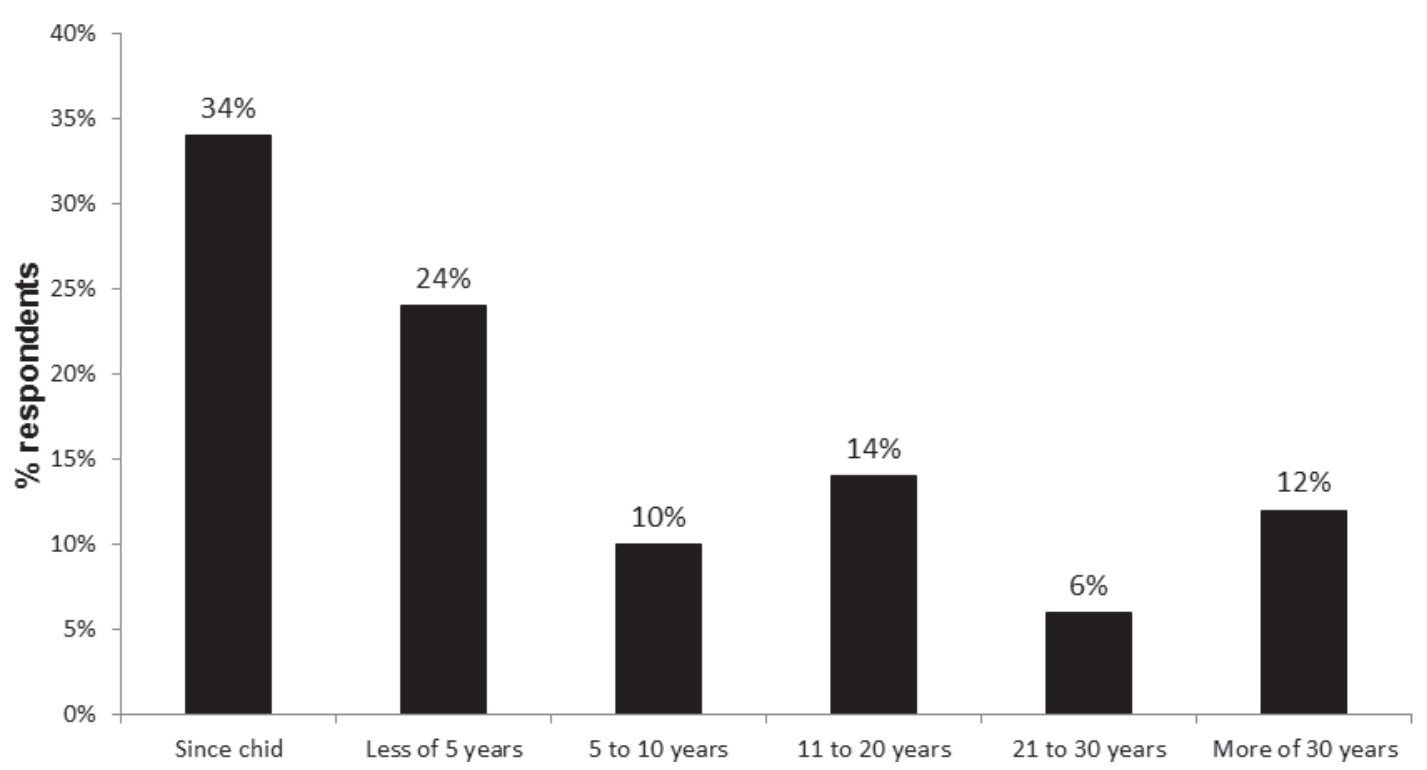

Figure 4 - How long breeders have kept birds as pets.

The PERCEPTIONS OF THE BREEDERS OF THE ENVIRONMENTAL IMPACTS CAUSED BY CAPTURING WILD BIRDS

Some of the bird breeders indicated that they were aware of the fact that the indiscriminant capture and commercialization of wild birds could lead to their disappearance:

"They disappear because of humans"

"Because they capture too many of them"

"In the old days all the birds had a lot, now there are regions that don't have any anymore, it depends on the time of year too"

"It's because of people that don't know how to take care of them, and wipe them out"

According to the bird breeders, separating mating pairs (through capture) makes them unable to reproduce in the forests, especially species like the Lesser Seed-finch Oryzoborus angolensis (Curió), the Yellow-faced Siskin Sporagra yarellii (Pintassilva), the Red-cowled Cardinal Paroaria 
dominicana (Galo-de-campina), the Common Tody-flycatcher Todirostrum cinereum (Ferreiro), the Blue-black Grassquit Volatinia jacarina (Tiziu), Crotophaga sp. (Anum), and the Chestnut-capped Blackbird Chrysomus ruficapillus (Corda-negra).

“The 'Pintassilva' and 'Gaturamo' were taken too much by the traffickers, they captured too many of them and they couldn't reproduce anymore in the forest"

"The took too many and didn't release the females"

"The traffickers take them to other countries, and they all die"

The Yellow-faced Siskin, Sporagra yarrelii (Pintassilva/Pintassilgo), was cited by $62 \%$ of the breeders as being very close to extinction, and this bird was seen in only two homes. Other birds cited as being rare were: Sicalis flaveola (Canárioda-terra), Amazona aestiva (Papagaio), and Gnorimopsar chopi (Craúna). Urbanization and the destruction of forests were also pointed out by bird breeders as factors that could cause birds to totally or partially disappear from the region. According to Santos and Costa-Neto (2007) alterations in forest environments will deprive certain species of their required habitats. Some of the breeders noted:

"They became extinct because of the growth of the city"

“They say it's extinction, but it's that they're disappearing with time. People are finishing off the forests"

"Extinction is happening because they're spraying the fields that fed them. Five years ago there were lots of Pintassilgo, you'd see lots of kids in the streets with cages"

According to some breeders, the presence of introduced species such as the house sparrow, Passer domesticus (Pardal), had impacted other bird species such as Euphonia violacea (Gaturamo), Sporophila nigricollis (Papa-capim), and Sporophila albogularis (Golado) and made them rare or even caused their to disappearance. Sparrows do, in fact, show agonistic behaviors that drive off most other bird species in the region.

"Sparrows destroy many small birds, they make nests on top of the nests of other birds and eat the eggs of others, too".

"They were the most abundant, but they disappeared because the sparrows took over"

\section{THE ECOLOGY OF THE BIRDS, ACCORDING TO THE}

ACCUMUlated KNOWLEDGE OF BREEDERS (SONGS, MOLTING, AND SEXUAL DiMORPHISM)

Bird breeders have accumulated considerable knowledge about the ecology of their pets, including their songs and appearance, the foods they eat, details of their reproduction and general behavior, and other aspects of their biology. This knowledge was usually acquired from the most experienced breeders and passed from father to son, although the owners are often excellent observers of bird behavior themselves and have picked up many details from their own pets. Gama and Sassi (2008) likewise found during their study of bird merchants in the public markets of João Pessoa-PB that bird breeders were usually "taught" by someone in their family (their father or oldest brother), but very rarely by a friend or neighbor.

According to the breeders, the females rarely sing or only softly sing short segments of the songs sung by the males of the same species ("cantam de corrida"); their singing is also considered less melodious than the males. The males sing much louder, have longer songs, and will sing for longer periods of time than the females ("de açoite" or "de estalo"); their singing is more melodious, smoother, and more pleasing than the females. The breeders interviewed also noted that the males sang in "disparada" (had prolonged vocalizations). Males are sold more frequently and for higher prices than the females as loud vocalizations are characteristic 
only of the males of most species (being used to delimit their territories and attract females) (Sisson and Grossman 2000).

According to the breeders, most species reproduce in the winter and this season is associated with more animated singing behavior by most birds. On the other hand, singing diminishes when the birds molt and the breeders attribute this to the fact that the birds became more fragile or weakened in that state.

A total of $94 \%$ of the breeders stated that molting was a very important period for the birds, and could occur from one to three times during the year (depending on the species). The number of molts in a year is also related to the age of the birds, and the breeders have observed that there are two basic types of molts ("reforma"): partial and general. A partial molt involves gradually exchanging some old feathers for new ones (during a three month period, twice a year), and the bird is never totally without feathers. A bird requires about six months to complete a general molt ("enxugála"), although this more complete exchange of feathers occurs only once a year.

Another event that occurs during the life cycle of a bird (although it was only cited by $6 \%$ of the breeders) is the renovation of its beak. Storer et al. (1998) noted that beaks grow continually to substitute losses resulting from use. The breeders interviewed in the present study would offer their birds soft foods (such as fruits) so that their beaks wouldn't break while being renewed, and they would also mix egg shells in the food to provide more calcium.

According to the breeders, birds that are changing their feathers or their beaks demonstrate behavioral modifications that involve alterations in their singing and eating. Most birds stop singing until molting is completely over, and the breeders also reported that some birds do not eat well while molting or when renewing their beaks. The bird breeders also noted that the renovation of the beak is a sign that the bird is growing old.
The breeders can distinguish sexual dimorphism in birds through a number of diverse characteristics such as differences in their songs, plumage, their beaks, their body size and pectoral region ("titela"), and their cloacae ("oveiro"). According to Berlin (1973), characteristics such as the sizes and colors of the birds allow many people to differentiate ethnospecies.

According to the interviewees, in most species only the male bird sings. This corroborates the observation made by Bottino et al. (2007) that there are significant morphological differences between the syrinx (an organ used in vocalization) of males and females. These differences allow the females to emit sonorous sounds, but the males to produce more intense singing. The breeders also affirmed that the plumage of the males is generally more colorful than that of the females. Las-Casas and Azevedo-Júnior (2009) likewise noted that sexual dimorphism in reflected in different plumage colors in many species as well as differences in the sizes of the birds' beaks (in agreement with the breeders in the present study).

\section{CONCLUSION}

The city of Campina Grande is known for having large numbers of people who keep birds as pets reflecting long-standing and trans-generational cultural practices. The birds are principally acquired in public markets or directly from other breeders. Trading birds is also widely practiced, especially with songbirds. The bird breeders were very knowledgeable about the life-cycles of the birds they kept and had noted that population declines in many species were related to environmental alterations and anthropogenic impacts.

Singing was the most important factor determining the specific preferences of the breeders for the 26 species of wild birds encountered in our survey, especially in terms of species belonging to the family Emberezidae. The popularity of birds 
as pets associated to the inefficiency of protective measures offered by the government have favored the growth of illegal commerce in wild animals.

Additional ethno-ornithological research will still be needed to describes the many ways birds are used by local human communities and the species they preferentially keep - and when this information is compared with ecological data evaluating extant bird communities it will aid in preparing and orienting reintroduction and environmental education programs in this region.

\section{ACKNOWLEDGMENTS}

The authors would like to thank the bird breeders in Campina Grande who provided the information presented in this study and who welcomed us into their homes. Additionally to the Coordenação de Aperfeiçoamento de Pessoal de Nível Superior (CAPES) for the grant awarded to the first and second author; and to Conselho Nacional de Desenvolvimento Científico e Tecnológico (CNPq) provided research fellowships to R. R. N. Alves. The authors would like to acknowledge to CNPq/ Edital Universal program (472623/2009-5 and 486005/2011-9) and to UEPB/PROPESQ (2008 and 2011) for financial support.

\section{RESUMO}

As aves destacam-se entre os animais mais utilizados pelas populações humanas. Em geral são bastante apreciadas como animais de estimação. Este estudo visou inventariar as aves silvestres utilizadas como animais de estimação na cidade de Campina Grande-PB Brasil, buscando informações sobre o motivo da sua escolha e sobre o conhecimento dos criadores acerca do comportamento e biologia das espécies criadas. A metodologia empregada envolveu entrevistas livres, entrevistas semiestruturadas, turnês guiadas e observação direta. Foram identificadas 26 espécies de aves, distribuídas em dez famílias e quatro ordens. A ordem encontrada com maior frequência foi a Passeriformes (76,9\%), com predominância de aves da família Emberizidae (34,6\%). Os espécimes são obtidos, principalmente, através do comércio em feiras livres ou entre os próprios criadores. Esse cenário, associado à popularidade das aves como animais de estimação e a ineficiência da fiscalização tem fomentado o crescimento do comércio e criação ilegal de aves em Campina Grande.

Palavras-chave: avifauna, criadores de aves, comércio de aves, conservação, etnozoologia, etnoornitologia.

\section{REFERENCES}

AlbuQuerque UP ET AL. 2012. Caatinga revisited: ecology and conservation of an important seasonal dry forest. Scient World J 2012: 205182.

Allgayer MC AND CzIUliK M. 2007. Reprodução de psitacídeos em cativeiro. Rev Bras Reprod Anim 31: 344-350.

AlMEIDA AV. 2005. Prescricões zooterápicas indígenas brasileiras nas obras de Guilherme Piso (1611-1679). In: ALVES AGC, LUCENA FP and ALBUQUERQUE UP (Eds), Atualidades em Etnobiologia e Etnoecologia, Nuppea, p. 47-60.

Alves RRN. 2009. Fauna used in popular medicine in Northeast Brazil. J Ethnobiol Ethnomed 5: 1-30.

ALVES RRN. 2012. Relationships between fauna and people and the role of ethnozoology in animal conservation. Ethnobiol Conserv 1: 1-69.

Alves RRN AND AlBUQUeRQUE UP. 2012. Ethnobiol and conservation: Why do we need a new journal? Ethnobio Conserv 1: 1-3.

Alves RRN AND Alves HN. 2011. The faunal drugstore: Animal-based remedies used in traditional medicines in Latin America. J Ethnobiol Ethnomed 7(9): 1-43.

ALVES RRN, GONÇALVES MBR AND VIEIRA WLS. 2012a. Caça, uso e conservação de vertebrados no semiárido Brasileiro. Tropical Conserv Scienc 5: 394-416.

Alves RRN, Leo Neto NA, SANTANA GG, VieIRA WLS AND ALMEIDA WO. 2009b. Reptiles used for medicinal and magic religious purposes in Brazil. Appl Herpetol 6: 257-274.

ALVES RRN, LIMA JRF AND ARAÚJO HF. IN PRESS. The live bird trade in Brazil and its conservation implications: an overview. Bird Conservation International DOI: http:// dx.doi.org/10.1017/S095927091200010X

Alves RRN, Lima HN, TAVARES MC, SOUTO WM, BARBOZA RR AND VASCONCEllos A. 2008a. Animalbased remedies as complementary medicines in Santa Cruz do Capibaribe, Brazil. BMC Compl and Altern Med 8(44): 1-9.

ALVES RRN, MENDONÇA LET, CONFESSOR MVA, VIEIRA WLS AND LOPEZ LCS. 2009a. Hunting strategies used in the semi-arid region of northeastern Brazil. J Ethnobiol Ethnomed 5(12): 1-12.

Alves RRN, Nougueira EEG, Araujo HFP AND BroOKS SE. 2010a. Bird-keeping in the Caatinga, NE Brazil. Hum Ecol 38: 147-156. 
ALVES RRN, OLIVEIRA MGG, BARBOZA RRD AND LOPEZ LCS 2010b. An Ethnozoological Survey of Medicinal Animals Commercialized in the Markets of Campina Grande, NE Brazil. Hum Ecol Rev 17: 11-17.

Alves RRN AND PEREIRA-Filho GA. 2007. Commercialization and use of snakes in North and Northeastern Brazil: implications for conservation and management. Biodivers Conserv 16: 969-985.

ALVES RRN, PEREIRA-FILHO GA, SILVA VIEIRAK, SOUTO WMS, MENDONÇA LET, MONTENEGRO PFGP, ALMEIDA WO AND VIEIRA WLS. 2012c. A zoological catalogue of hunted reptiles in the semiarid region of Brazil. J Ethnobiol Ethnomed 8(27): 1-29.

ALVES RRN AND RosA IL. 2007. Zootherapy goes to town: The use of animal-based remedies in urban areas of NE and $\mathrm{N}$ Brazil. J Ethnopharmacol 113: 541-555.

ALVES RRN AND RosA IL. 2010. Trade of animals used in Brazilian traditional medicine: trends and implications for conservation. Hum Ecol 38: 691-704.

Alves RRN, Rosa IL, LÉO Neto NA AND Voeks R. 2012d. Animals for the Gods: Magical and Religious Faunal Use and Trade in Brazil. Hum Ecol 40: 751-780.

Alves RRN, Rosa IL AND SANTANA GG. 2007. The Role of Animal-derived Remedies as Complementary Medicine in Brazil. BioScience 57: 949-955.

ALVES RRN AND SouTO WMS. 2011. Ethnozoology in Brazil: current status and perspectives. J Ethnobiol Ethnomed 7(22): 1-18.

Alves RRN, SOUTO WMS AND BARBOZA RRD. 2010c. Primates in traditional folk medicine: a world overview. Mammal Review 40: 155-180.

Alves RRN, VIEIRA WLS AND SANTANA GG. 2008b. Reptiles used in traditional folk medicine: conservation implications. Biodivers Conserv 17: 2037-2049.

Alves RRN, VIEIRA KS, SANTANA GG, VIEIRA WLS, Almeida WO, SOUTO WMS, MONTENEGRo PFGP AND PEZZUTI JCB. 2011. A review on human attitudes towards reptiles in Brazil. Environm Monit and Assessm 184: 6877-6901.

BAILEY KD. 1982. Methods of Social Research. $4^{\text {th }}$ ed., The Free Press, New York, 592 p.

BARbosa JAA, Nobrega VA AND ALVES RRN. 2011. Hunting practices in the semiarid region of Brazil. Indian J Tradit Know 10: 486-490.

BEZERRA DMM, ARAUJO HFP AND ALVES RRN. 2012. Captura de aves silvestres no semiárido brasileiro: técnicas cinegéticas e implicações para conservação. Tropical Conserv Scienc 5: 50-66.

BERLIN B. 1973. The relation of folk systematics to biological classification and nomenclature. Ann Rev Ecol and Syst 4: 259-271.

Bottino F, Artoni SMB, Oliveira D, PACHeco MR, Amoroso L, TOVAR MCH AND SAgula A. 2007. Dimorfismo sexual da traquéia e siringe de periquito (Touist sp.). Arq Bras Med Vet Zootec 59: 1489-1492.
CBRO - COMITÊ BRASILEIRO DE REGISTROS ORNITOLÓGICOS. 2011. Lista de Aves do Brasil. 10 a edição. Disponível em: $<$ http://www.cbro.org. br>. Acesso em: 03 de dez. de 2012.

CONFESSOR MA, MENDONCA LET, MOURÃo JS AND AlVES RRN. 2009. Animals to heal animals: ethnoveterinary practices in semi-arid region, Northeastern Brazil. J Ethnobiol Ethnomed 5(37): 1-9.

Costa RGA. 2005. Comércio ilegal de aves silvestres em Fortaleza, Ceará. Atualidades Ornitológicas 3: 1-12.

Costa-Neto EM AND Marques JGW. 2000. Conhecimento Ictiológico Tradicional e a Distribuição temporal e espacial de recursos pesqueiros pelos pescadores de Conde, Estado da Bahia, Brasil. Etnoecológica 4: 56-67.

Dias TLP, Leo Neto NA AND Alves RRN. 2011. Molluscs in the marine curio and souvenir trade in NE Brazil: species composition and implications for their conservation and management. Biodivers Conserv 20: 2393-2405.

Fernandes-Ferreira H, MENDONÇA SV, Albano C, FERREIRA FS AND Alves RRN. 2012. Hunting, use and conservation of birds in Northeast Brazil. Biodivers and Conserv 21: 221-244.

FERREIRA CM AND GLOCK L. 2004. Diagnóstico preliminar sobrea avifauna traficada no Rio Grande do Sul, Brasil. Biociências 12: 21-30.

FERrEIRA FS, BRITO SV, RIBEIRO SC, ALMEIDA WO AND ALVES RRN. 2009. Animal-based folk remedies sold in public markets in Crato and Juazeiro do Norte, Ceará, Brazil. BMC Compl and Altern Med 9: 1-8.

FREITAS MA. 1998. Avifauna de Importância Cinegética encontrada no Comércio Ilegal de Feira de Santana. DCHF/ UEFS, Feira de Santana, BA. Atualidades Ornitológicas 89:10.

FRISCH J. 1981. Aves Brasileiras. Dalgas- Ecoltec Ecologia Técnica: São Paulo, 353 p.

GAMA TP AND SASSI R. 2008. Aspectos do comércio ilegal de pássaros silvestres na cidade de João Pessoa, Paraíba, Brasil. Gaia Scientia 2: 1-20.

IBGE. 2008. <http:// www.ibge.com.br/cidadesat/topwindow.htm> Último acesso em 20 de nov. de 2008

JURAS IAGM. 2006. Consequências do uso do chumbo na pesca. Câmara dos Deputados. Praça 3 Poderes. Consultoria Legislativa. Anexo III - Térreo. Brasília - DF. Estudo - Junho.

LAS-CASAS FMG AND AZEVEDO-JÚNIOR SM. 2009. Dimorfismo sexual de tamanho no beija-flor-de-costasvioletas Thalurania watertonii (Bourcier, 1847) (Aves: Trochilidae): implicações ecológicas. Ornithol 3: 83-89.

Leo Neto NA, Brooks SE AND Alves RRN. 2009. From Eshu to Obatala: animals used in sacrificial rituals at Candomble terreiros in Brazil. J Ethnobiol Ethnomed 5: 1-10.

LeO Neto NA, MourÃo JS AND Alves RRN. 2011. "It all begins with the head": initiation rituals and the symbolic conceptions of animals in Candomblé. J Ethnobiol 31: 244-261.

Leo Neto NA, Voeks RA, Dias TLP AND Alves RRN 2012. Mollusks of Candomble: symbolic and ritualistic importance. J Ethnobiol Ethnomed 8: 1-10. 
OLIVEIRA ES, TÔRRES DF, BROOKS SE AND ALVES RRN. 2010. The medicinal animal markets in the metropolitan region of Natal City, Northeastern Brazil. JEthnopharmacol 130: 54-60.

Pagano ISA, Sousa AEBA, Wagner PGC AND RAmos RTC. 2009. Aves depositadas no Centro de Triagem de Animais Silvestres do IBAMA na Paraíba: uma amostra do tráfico de aves silvestres no estado. Ornithol 3: 132-144.

Pereira AG AND BRITO MT. 2005. Diversidade de aves silvestres brasileiras comercializadas nas feiras livres da Região Metropolitana do Recife, Pernambuco. Atualidades Ornitológicas 126: 1-14.

Perlo BV. 2009. A field guide to the birds of Brazil. Oxford University Press, $465 \mathrm{p}$.

Posey DA. 1986. Etnobiologia: teoria e prática. In: RIBEIRO D (Ed), Suma Etnológica Brasileira. v. 1, Etnobiologia. Petrópolis: Vozes/FINEP, p. 15-25.

RENCTAS. 2001. $1^{\circ}$ Relatório nacional sobre o tráfico de fauna silvestre. Rede Nacional de Combate ao Tráfico de Animais Silvestres, Brasília, 108 p.

RidGely RS AND TUdOR G. 2009. Field guide to the songbirds of South America: the passarines. University of Texas Press, $750 \mathrm{p}$.

RoCHA MSP, CAVALCANTI PCM, SOUSA RL AND ALVES RNA. 2006. Aspectos da comercialização ilegal de aves nas feiras livres de Campina Grande, Paraíba, Brasil. Rev Biol Ciênc Terra 6: 204-221.

ROCHA MSP, MOURÃo JS, SOUTO WMS, BARBOZA RRD AND ALVES RRN. 2008. Uso dos recursos pesqueiros no Estuário do Rio Mamanguape, Estado da Paraíba, Brasil. Interciencia 33: 903-909.

Rodrigues JE, GAUDÊNCIO EO AND ALMEIDA FILHO S. 1996. Memorial Urbano de Campina Grande-PB, A União.

Rosa IL, Oliveira TPR, OsÓrio FM, MORAEs LE, CASTro ALC, BARRos GML AND Alves RRN. 2011. Fisheries and trade of seahorses in Brazil: historical perspective, current trends, and future directions. Biodivers Conserv 20: 1951-1971.
SAntos IB AND CostA-Neto EM. 2007. Etnoornitologia no semi-árido baiano. Sitientibus Ser. Ci Biol 7: 273-288.

SICK H. 1997. Ornitologia brasileira. Nova Fronteira. RJ. Brasil, $912 \mathrm{p}$.

SisSON S AND GROSSMAN JD. 2000. Anatomia dos animais domésticos. $5^{\mathrm{a}}$ ed., Rio de Janeiro: Guanabara Koogan, $1986 \mathrm{p}$.

SOUTO WMS, MOURÃo JS, BARBOZA RRD AND ALVES RRN. 2011. Parallels between zootherapeutic practices in Ethnoveterinary and Human Complementary Medicine in NE Brazil. J Ethnopharmacol 134: 753-767.

SOUZA GM AND SOARES-FILHO AO. 2005. O comércio ilegal de aves silvestres na região do Paraguaçu e Sudoeste da Bahia. Enciclopédia Biosfera 1: 10.

Storer TI, Usinger RL, Stebbins RC AND NybakKen JW. 1998. Zoologia geral. $6^{\mathrm{a}}$ ed., Companhia Editora Nacional. São Paulo.

TIDEMANN S AND GOSLER A. 2010. Ethno-ornithology: birds, indigenous, peoples, culture and society. Earthscan, London, $346 \mathrm{p}$.

TÔRRES DF, OliveIra ES, ALVes RRN AND Vasconcellos A. 2009. Etnobotânica e etnozoologia em unidades de conservação: uso da biodiversidade na Apa de Genipabu, Rio Grande do Norte, Brasil. Interciência 34: 623-629.

Trinca CT AND Ferrari SF. 2006. Caça em assentamento rural na amazônia matogrossense. In: JACOBI $\mathrm{P}$ and FERREIRA LC (Eds), Diálogos em ambiente e sociedade no Brasil. ANPPAS, Annablume, Indaiatuba, p. 155-167.

Vidolin GP, MANGINI PR AND Muchailh MC. 2004. Programa estadual de manejo de fauna silvestre apreendida - Estado do Paraná, Brasil. Cad Biodivers 4: 37-49. 